\title{
Geology and sedimentology of the Upper Devonian Escuminac Formation, Quebec, and evaluation of its paleoenvironment: lacustrine versus estuarine turbidite sequence
}

\author{
Reinhard Hesse and Hemdat Sawh \\ Department of Earth and Planetary Sciences, McGill University, 3450 University Street, \\ Montreal, Quebec H3A 2A7, Canada
}

Date Received February 24, 1992

Date Accepted September 11, 1992

\begin{abstract}
The Escuminac Formation of the Upper Devonian Miguasha Group at the western end of Chaleurs Bay, Quebec, famous for its fossil fish fauna, is a turbidite sequence whose environment of deposition has been a matter of debate. Interpretations vary with different authors between lacustrine or brackish to coastal marine. It is possibly of estuarine origin. Its total stratigraphic thickness of $117 \mathrm{~m}$ has been divided into eight lithostratigraphic units on the basis of vertical changes in sandstone:shale ratio. A lacustrine setting is feasible in view of the association with fluvial formations below (Fleurant Formation) and above (Bonaventure Formation), although these are separated by a disconformity or an angular unconformity from the Escuminac. The lack of any shelly marine invertebrate fauna is negative evidence indirectly favoring a lacustrine origin. Periodically stagnant bottom-water conditions evidenced by the preservation of laminites are compatible with a lake environment. The fossil fish fauna, however, contains elements which point toward brackish or marine environments. Geochemical evidence also seems to support brackish conditions, although it is not clear to what extent the geochemical signature may have been inherited from older marine detrital clays. A silled estuary would best accommodate the different lines of evidence, but poses problems of fitting into the broadscale paleogeographic picture of the Upper Devonian Old Red Continent.
\end{abstract}

La Formation d'Escuminac du Groupe de Miguasha du Dévonien supérieur, dans la partie ouest de la baie des Chaleurs, Québec, célèbre pour sa faune de poissons fossile, est une séquence de turbidites dont l'environnement de déposition a fait l'objet de discussions. Les interprétations varient suivant les différents auteurs entre lacustre ou saumâtre à marin côtier. C'est possiblement d'origine estuarienne. Son épaisseur totale de $117 \mathrm{~m}$ a été divisée en huit unités lithostratigraphiques sur la base de variations verticales dans le rapport grès:shale. Un milieu lacustre est possible en regard de l'association avec les formations fluviatiles en-dessous (Formation de Fleurant) et au-dessus (Formation de Bonaventure), bien qu'elles soient séparées de l'Escuminac par une inconformité ou une discordance angulaire. L'absence de toute faune marine invertébrée à coquille est un argument négatif favorisant indirectement une origine lacustre. Des conditions d'eau de fond périodiquement stagnante, indiquées par la préservation de laminites, sont compatibles avec un environnement de lac. La faune de poissons fossile, cependant, contient des éléments qui pointent vers des environnement saumâtres ou marins. Les données géochimiques semblent aussi appuyer des conditions saumâtres, bien qu'il ne soit pas clair jusqu'à quel point la signature géochimique ait pu être héritée d'argiles marines plus anciennes. Un estuaire endigué accomoderait le mieux les diverses données, mais rencontre des difficultés à s'incrire dans le cadre paleogéographique à grande échelle du continent Old Red du Dévonien supérieur.

[Traduit par le journal]

\section{INTRODUCTION}

Clastic sedimentary rocks of the Miguasha Group, exposed in the sea cliffs at the western end of Chaleurs Bay, Quebec (Fig. 1), are of considerable regional geologic significance because they represent one of the few existing records of Late Devonian sedimentation in eastern Canada. The Miguasha Group consists of two formations, the lower Fleurant Conglomerate and the upper Escuminac Formation. The latter has attracted attention from vertebrate paleontologists worldwide because of its unusually rich and wellpreserved fossil fish fauna (Schultze and Cloutier, in press). Appropriately, the locality at Miguasha has become the site of a Museum of Natural History, established by the Government of Quebec, where many of the extraordinarily wellpreserved fossil specimens from the Escuminac Formation are on display.

The Escuminac Formation has been the subject of continued scientific debate over its environment of deposition, which has been interpreted alternatively as lacustrine ( $\mathrm{Di}$ neley and Williams, 1968a) or marine (Schultze and Arsenault, 1985). In this paper, a comprehensive review of the general geology is presented together with the results of a sedimentologic-diagenetic restudy as a contribution to the ongoing debate about the depositional environment. 


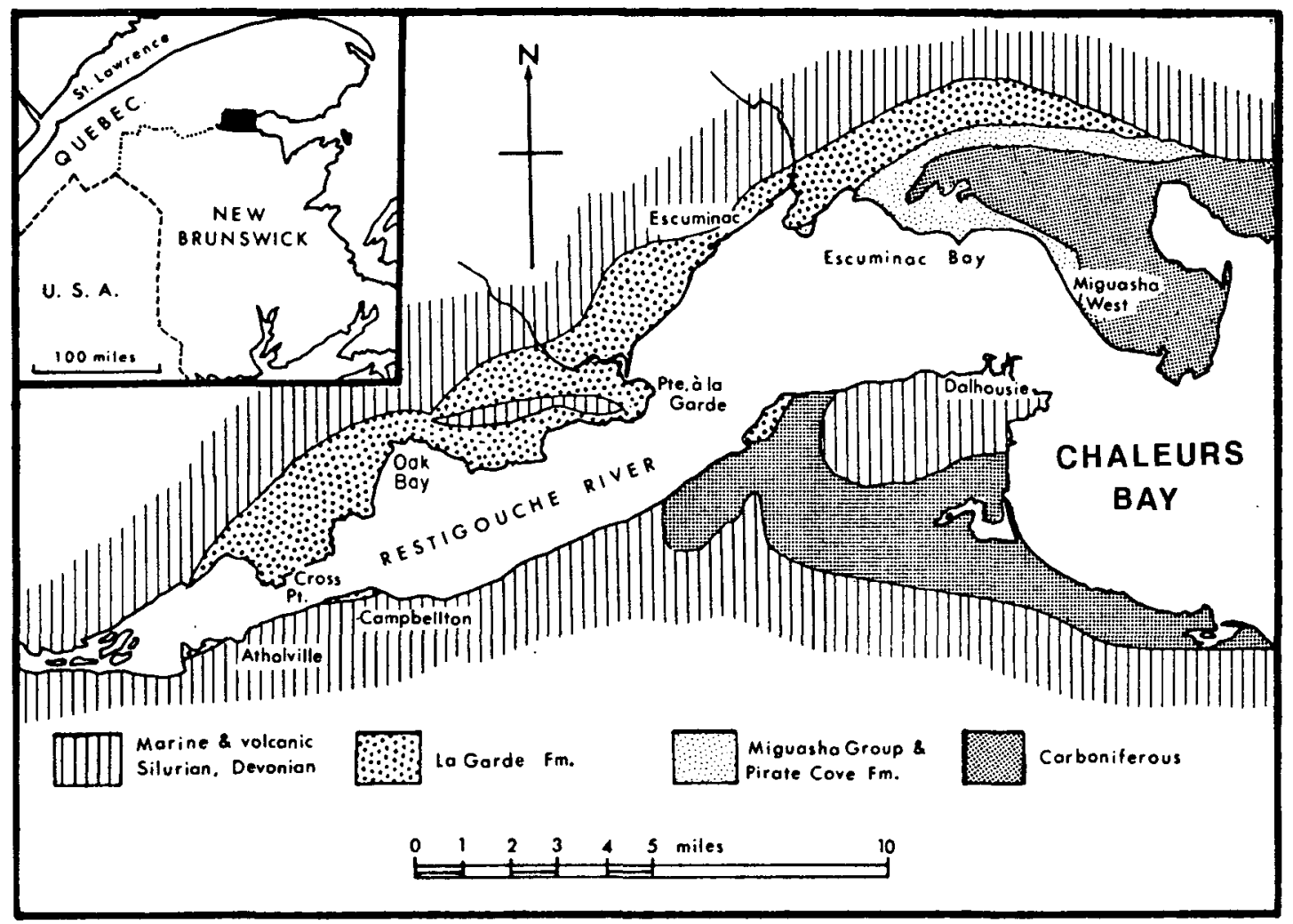

Fig. 1. Geology of western end of Chaleurs Bay (from Dineley and Williams, 1968b).

\section{Upper Devonian Geology of Western Chaleurs Bay Region}

\section{Exposure of Escuminac Formation}

The Escuminac Formation is exposed in the sea cliffs of Miguasha Bay along the south shore of Gaspé Peninsula over a distance of about $7 \mathrm{~km}$ and covers a total inland area probably not exceeding $7 \mathrm{~km}^{2}$. Outcrops are more or less limited to four coastal sections west and east of Miguasha Wharf. (1) Scattered exposures occur along the coast between Smiley Brook and Fleurant Point. (2) From about 0.5 $\mathrm{km}$ east of Fleurant Point to $0.3 \mathrm{~km}$ west of Miguasha Wharf, exposures are continuous. (3) They resume another $0.5 \mathrm{~km}$ east of the wharf for a short distance and (4) next occur $2.5 \mathrm{~km}$ east of the wharf at Yacta Point (Fig. 2). Inland exposures are sparse to non-existent. Best exposed is section (2) west of the wharf which covers the complete $117 \mathrm{~m}$ of stratigraphic thickness of the formation and is accessible at low tide. The formation is gently folded into broad synclines and anticlines with dips generally less than $25^{\circ}$, except at Yacta Point where deformation has been more intense and the east flank of a northeast plunging asymmetrical anticline dips nearly vertically.

\section{Relationship to other stratigraphic units}

Continental Devonian rocks of Gaspé Peninsula have attracted attention since the days of Logan (e.g., 1846), but a stratigraphic framework was only established during systematic mapping by the Geological Survey of Canada in the Gaspésie during the first half of this century (Kindle, 1930; Alcock, 1935). Williams and Dineley's (1966) revised stratigraphy recognized an important unconformity between the Fleurant Formation and the underlying Pirate Cove Formation in addition to the already known unconformities (Table 1) between (i) the Carboniferous Bonaventure Formation and the Escuminac and (ii) the La Garde Formation and underlying Atholville Beds of the Dalhousie Group. The Pirate Cove Formation was assigned a Middle Devonian age by these authors (instead of the previous Late Devonian age of Alcock, 1935) and Alcock's unconformity between the Pirate Cove and $\mathrm{La} \mathrm{Garde}$ formations discounted, whereas it is still retained (Fig. 2) by Rust (1982).

\section{Tectonic setting and orogeny}

Overall, deformation associated with the Acadian orogeny at the western end of Chaleurs Bay during the Devonian was mild and generated only gentle fold structures and strikeslip and normal faults. Devonian deformation in the less than $500 \mathrm{~km}$ wide Acadian belt in Maine, New Brunswick and eastern Quebec was diachronous. According to Donohoe and Pajari (1973), the Acadian orogeny started earliest in southeastern Maine (in the Early Devonian) and reached the northern margin of the belt in Quebec last (in late Middle Devonian to early Late Devonian time), with Chaleurs Bay being affected some time in between. Bradley (1983) attrib- 


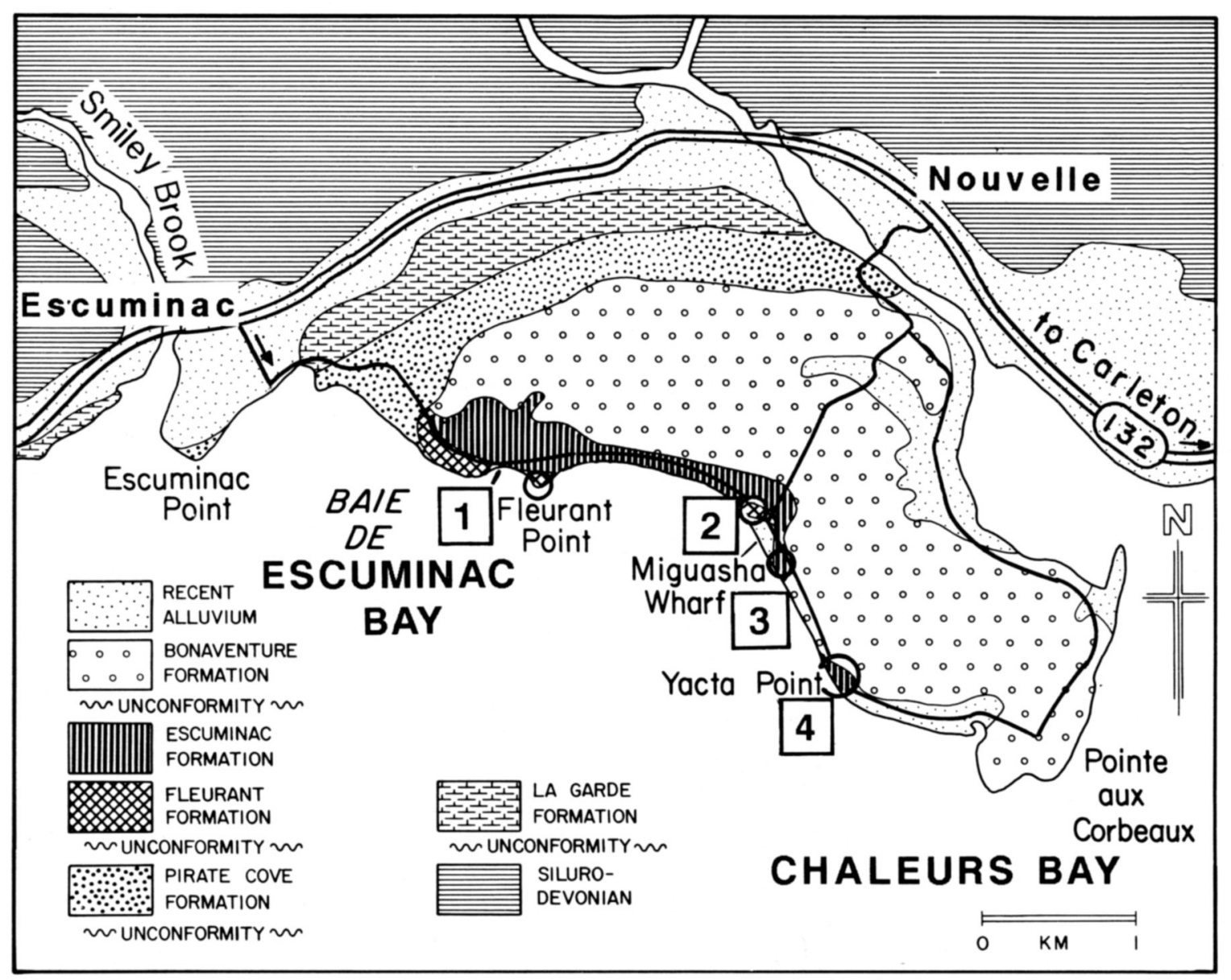

Fig. 2. Geologic map of Miguasha Bay showing location of cliff sections numbers 1 to 4 of the Escuminac Formation (modified from Rust, 1982).

uted the orogeny to northwestward subduction of an oceanic terrain to the south (Merrimack Trough, Fredericton/Aroostook-Matapedia Trough), which generated the Silurian/Middle Devonian Piscataquis volcanic arc (Fig. 3) in north-central Maine and the Chaleurs Bay area (e.g., volcanics of the Dalhousie Group) and created a back-arc basin (Connecticut Valley-Gaspé Trough). By Middle Devonian time this basin, which at one point in its evolution had been deep-marine (Lower Devonian Fortin Group; Hesse and Dalton, 1990), had been filled up and emerged collecting continental detritus. In eastern Gaspé, these continental facies started in latest Early to Middle Devonian time with fluvial deposits of the Battery Point and Malbaie formations, collectively known as the Gaspé Sandstone Group (Table 1); these overlie earlier shallow marine sediments (i.e., York River and York Lake formations, Upper Gaspé Limestone Group). Together, the marine and continental successions form an upward coarsening, $5 \mathrm{~km}$ thick clastic wedge (Rust et al., 1989). The continental succession of western Chaleurs Bay including the Miguasha Group would have been deposited in subaerial parts of the still active or abandoned island arc. In this scenario, the subduction was terminated by continental collision which created the Upper Devonian Old Red Continent.
Williams (1979) cautioned against a subduction/continent-continent collision model for the Acadian orogeny because of the absence of tectonic elements related to oceanic closure such as ophiolites and melanges. There is no evidence for a Devonian suture. According to Williams, elimination of Iapetus, the major ocean between North America (Laurentia), Europe and Africa, had taken place in the Taconian orogeny during the Ordovician, and the Silurian-Devonian basins were successor basins of this orogeny. Silurian-Devonian volcanism may not have been plate-boundary volcanism but of an intraplate nature, unrelated to subduction (Laurent and Bélanger, 1984; Bédard, 1986). The Acadian deformation may thus reflect wrench-fault tectonics with oblique continental convergence. Outboard terranes may have docked with the orogen, involving major transcurrent motion (Williams and Hatcher, 1983). Major dextral strikeslip faulting is supported by structural analysis in southern Gaspé Peninsula (Bourque et al., 1985; Kirkwood and St. Julien, 1987). Isolated strike-slip half-grabens or intermontane successor basins may thus have been the receptacles for continental sequences such as that of western Chaleurs Bay (Zaitlin, 1981; Rust, 1982; Rust et al., 1989). 
Table 1. Stratigraphy of the Taconian and Acadian orogenic belts of Gaspé Peninsula (from Hesse and Dalton, 1991, after stratigraphic compilation in Bourque et al., 1989).

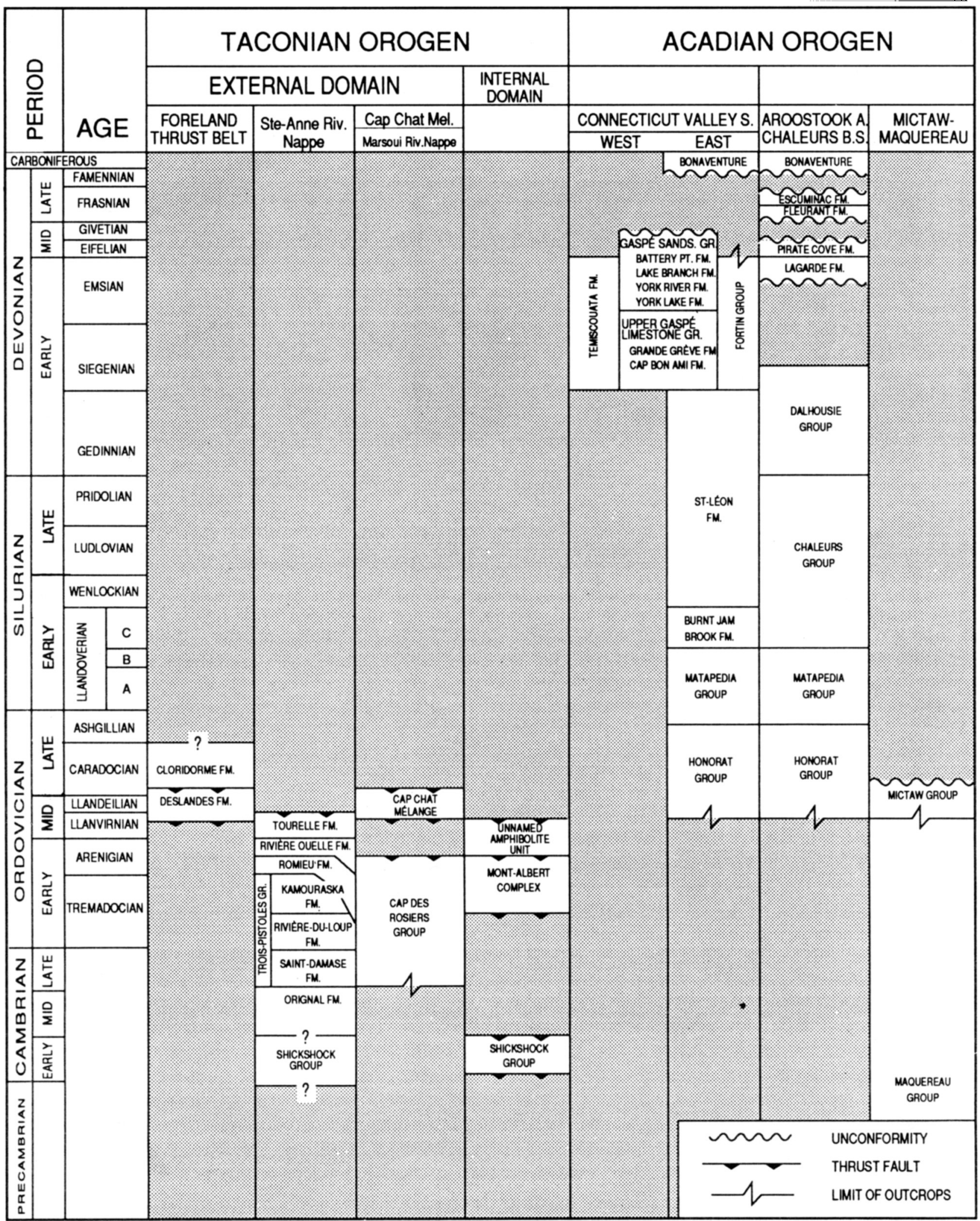




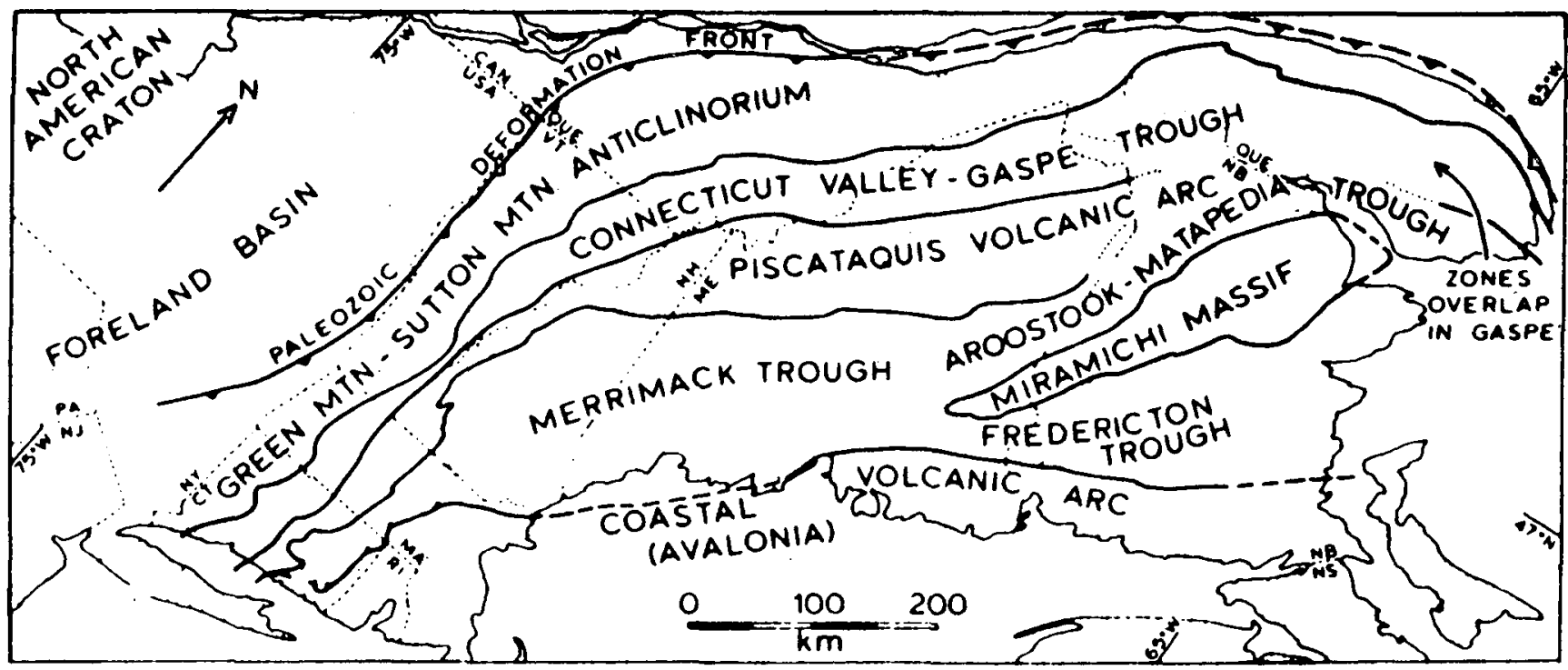

Fig. 3. Siluro-Devonian paleogeographic features of the Acadian belt, Maritime Provinces, Quebec and New England States (modified from Bradley, 1983).

\section{Stratigraphy and fossil content of Escuminac Formation}

The Late Devonian (Frasnian) age of the Escuminac Formation is based on Ørvig's (1957) work on the vertebrate fauna and the study of miospores by Brideaux and Radforth (1970). The Escuminac Formation has provided one of the richest Devonian fish faunas in North America, with 22 species exclusive to the formation; these are listed here (Table 2) because their habitats may provide constraints on the environmental interpretation (see section on coastal marine environment) for the formation.

The list shows that all major groups of Devonian fish are present in the Escuminac Formation except the Chondrichthyes. Most common are species of Bothriolepis. Recent work has shown that Elpistostege watsoni Westoll, formerly thought to be a tetrapod, is a panderichthyid fish, possibly a close tetrapod relative (Schultze and Arsenault, 1985). Another development is the reinterpretation of the problematical Scaumenella mesacanthi as an acanthodian (Triazeugacanthus affinis) degraded during fossilization (Béland and Arsenault, 1985).

In addition, plant fossils are abundant at certain stratigraphic levels (Arnold, 1936). Most common are fragments of coalified stems and leaves of Archaeopteris (=Callixylon), an arborescent progymnosperm. Other plant fossils found in the Escuminac Formation include Flabellofolium brownianum Dawson, the gymnosperm megaspore Spermasporites devonicus and nearly fifty types of miospores; on the basis of these, an Early Frasnian age was assigned to the Escuminac Formation by Brideaux and Radforth (1970). These authors commented that the abundance and diversity of fossil plants in the Escuminac Formation indicate a significant terrestrial flora, with aquatic plants present as well. In conjunction with the striking absence of any shelly marine invertebrate fauna, this has been a strong argument in favor of a continental depositional environment. Among the invertebrates, only some arthropods have been found, including fragments of eurypterids, some scorpions (Petaloscorpio bureaui, Kjellesvig-Wearing; and Eoscorpius) and the branchiopod Asmusia.

\section{Sedimentology}

The Escuminac Formation is a turbidite formation thought to be of lacustrine origin by Dineley and Williams (1968a). Although deposition in a lacustrine environment is debatable and will be discussed below, the turbiditic nature of the sandstone and siltstone layers of the formation is not in question. It is based on the sequences of internal sedimentary structures, dominated by lower-division parallel lamination (Fig. 4a), ripple-cross lamination which is often climbing, and upper-division parallel lamination. Graded or massive divisions, convolute lamination and ball-and-pillow structure are less common. One of the basal beds in the type section displays cross-bedding and wavy bedding. Although such structure sequences are also common in fluvial overbank deposits on natural levees of rivers, the complete absence of other typical fluvial facies such as fining upward point-bar sequences excludes a fluvial origin. Also, sole marks on the sandstone beds of the Escuminac are much more abundant than usual in fluviatile deposits and include flute and grove casts, brush and prod casts, rill casts which bifurcate downstream, squamiform load casts and other linear structures. Some beds east of the Miguasha Wharf carry superposed sets of flute casts which indicate opposing current directions because they include a $120^{\circ}$ angle (Fig. 5a). The older set was perhaps caused by a bottom current, the younger set by the turbidity current which deposited the bed. Paleocurrent directions determined from flute and groove 
Table 2. List of fossil fish from the Upper Devonian Escuminac Formation (from Carroll et al., 1972).

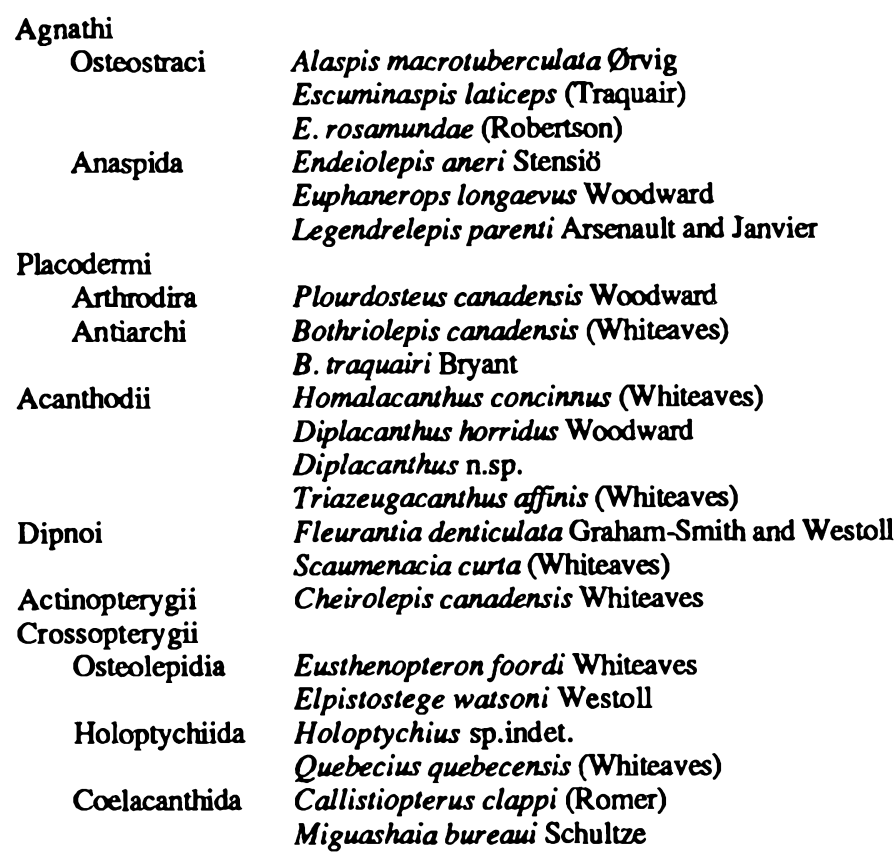

casts (Fig. 6) point almost uniformly towards WSW (Dineley and Williams, 1968a).

The poorly sorted sandstones are medium- to fine- and very fine-grained subarkosic arenites containing 5 to $10 \%$ feldspar and 50 to $70 \%$ detrital quartz, and minor mica and chlorite. They are compositionally and texturally immature. They are calcite cemented except at the base of the formation where some very poorly indurated beds occur. Some beds show evidence of micro-faulting prior to cementation (Figs. $4 \mathrm{~b}, 5 \mathrm{~b})$, possibly recording paleoseismic activity.

Two types of fine-grained sedimentary rocks occur: (i) greenish-grey shales and (ii) thin layers of varve-like laminites, called "rhythmites" by Dineley and Williams (1968a). The latter show millimetre-thick alternating dark and light laminae. The light, somewhat thicker laminae consist predominantly of silt-sized calcite and quartz, the dark laminae of clay minerals, finely disseminated pyrite and organic matter. The significance of the laminites for the interpretation of the depositional environment (see below) is that they indicate the absence of benthonic life, probably reflecting periodically, and consequently periodically stagnant, anoxic bottom water. Wherever bottom-living organisms are present, fine-grained sediment will be bioturbated and does not preserve lamination. It will become mottled. This is the normal situation under oxidizing conditions. The lamination may reflect seasonal variations, as has been suggested for modern lake sediments. The proportion of laminites in the Escuminac section is relatively small $(<5 \%)$ and individual layers are thin, not exceeding $80 \mathrm{~cm}$. Usually they are less than 10 to $15 \mathrm{~cm}$ thick. Their cumulative thickness in the type section is $5.45 \mathrm{~m}$. Periods of stagnation of the bottom waters thus probably affected only a small fraction of the total time represented by the Escuminac Formation.

\section{Diagenesis}

A fourth layered sediment-type besides the sandstones, shales, and laminites is diagenetic in origin, this is fibrous calcite, first mentioned by Dineley and Williams (1968a,b). It forms layers up to $4 \mathrm{~cm}$ thick and, under the microscope, consists of cone-in-cone calcite cement. It originates from the early diagenetic decomposition of organic-matter which generates alkalinity and, if accompanied by iron reduction and ammonia production, a high enough $\mathrm{pH}$ for carbonate precipitation (Middelburg, 1990; Slaughter and Hill, 1991). Carbon-isotopic results confirm the early diagenetic origin of the fibrous calcite in the methane-generation zone (Chidiac, 1989). Our preliminary analyses of a single sample gave $\delta^{13} \mathrm{C} / \delta^{18} \mathrm{O}$ pairs of $0.3 /-9.3$ (older subsample near apex of cone-in-cone calcite) and $-0.3 /-10.1$ (younger subsample near cone opening), respectively, which fall well within the total range of values $(0.7 /-9.6$ to $-0.6 /-11.6)$ obtained by Chidiac.

Likewise, abundant calcite concretions both in the sandstones and shales result from calcite cementation triggered by organic-matter decomposition, although their mode of formation is different from that of the fibrous calcite. In the concretions, precipitation of micritic calcite fills the existing pore space by replacing the pore water. Precipitation occurred during early diagenesis in the methane-generation zone, like the fibrous calcite, and is also confirmed isotopically. Five subsamples from one concretion gave $\delta^{13} \mathrm{C} / \delta^{18} \mathrm{O}$ pairs ranging from $-1.0 /-10.8$ (centre of concretion) to $0.7 /$ 11.2 or $0.4 /-12.4$ (concretion margin), approximately within the range of Chidiac's (1989) analyses. In the fibrous calcite layers, the growing crystals create their own space by actively pushing the adjacent sediment up as can be concluded from structural evidence seen under the microscope. This is possible because the cone-in-cone calcite is a low nucleationrate cement (Füchtbauer, 1971). Where fibrous calcite forms in laminites, the cone-in-cone calcite preferentially uses light laminae as substrate for nucleation and grows in opposite directions on both sides of a given lamina, with the cone opening pointing toward dark laminae. The calcite may contain euhedral pyrite of several millimetres edge length. Widespread pyrite formation is another early diagenetic mineralization phenomenon, which plays an important role in the paleoenvironment analysis for the Escuminac Formation. Apart from its occurrence in fibrous calcite, pyrite occurs either finely disseminated as, for example, in the dark laminae of the laminites, or in the form of framboids up to 2 $\mathrm{cm}$ in diameter, often on sandstone bedding planes (Fig. 4c).

In order to assess the level of maximum burial of the Escuminac Formation, illite crystallinity and vitrinite reflectance were determined for shale and sandstone samples, respectively. $X$-ray diffraction of the $<2 \mu \mathrm{m}$ fraction of shales showed the presence of illite, chlorite, smectite-chlorite mixed 

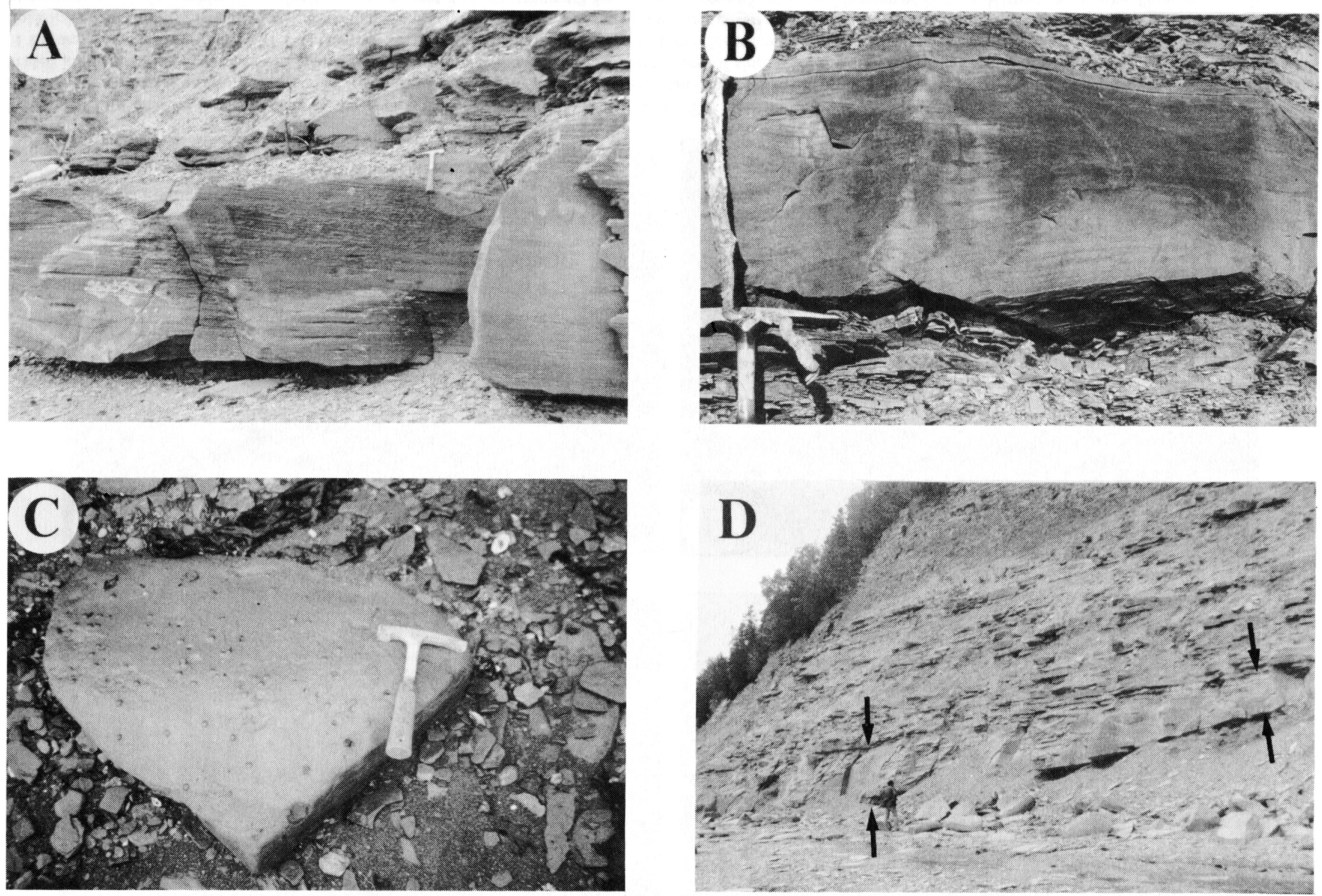

Fig. 4. (A) Parallel-laminated and low-angle climbing-ripple laminated fine-grained sandstone turbidite. Section west of Miguasha Wharf. (B) Soft-sediment micro-faulting of laminated muds and silts cast by overlying sandstone turbidite which does not contain any healed joints showing that it was unconsolidated at the time of faulting. Cross-sectional view of similar feature shown in oblique bottom view in Figure 5B. Section east of Miguasha Wharf. (C) Framboidal pyrite up to 1 to $2 \mathrm{~cm}$ in diameter concentrated on the basal face of a sandstone turbidite, block in talus at locality of Figure 4D. (D) Channelized(?) sandstone turbidite (between arrows) rapidly thickening towards west (left-hand side of picture). 

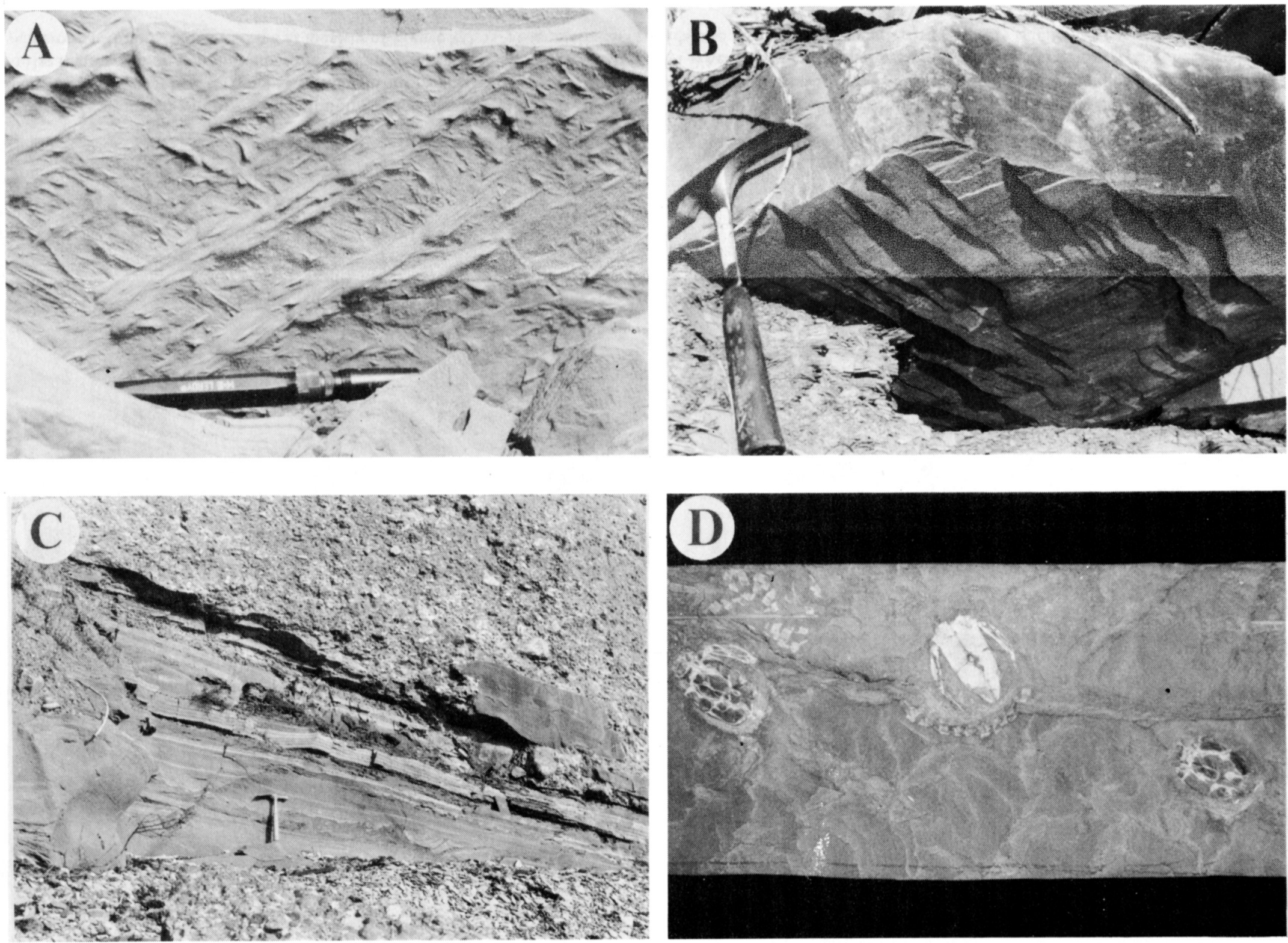

Fig. 5. (A) Two interfering sets of flute casts showing paleocurrent directions $120^{\circ}$ apart. The older set consists mainly of trace fossils overprinted by a current. Section east of Miguasha Wharf. (B) Early soft-sediment micro-faulting of weakly consolidated mud (stair-step pattern of normal faults) cast by overlying sandstone which does not contain any healed joints. Faulting occurred prior to cementation of the sandstone. Oblique bottom view of similar feature shown in cross-section in Figure 4B. (C) Large individual block of Escuminac sandstone at base of Bonaventure Formation unconformably overlying the Escuminac Formation. Section east of Miguasha Wharf. (D) Three individuals of Bothriolepis in ripple cross-laminated division of fine-grained turbidite, heads all pointing upcurrent. Did they try to escape the turbidity current, or were they just aligned in hydrodynamically favorable orientation for passive, post-mortem transport? Specimen is about $65 \mathrm{~cm}$ long. Museum of Natural History, Miguasha, Quebec. 

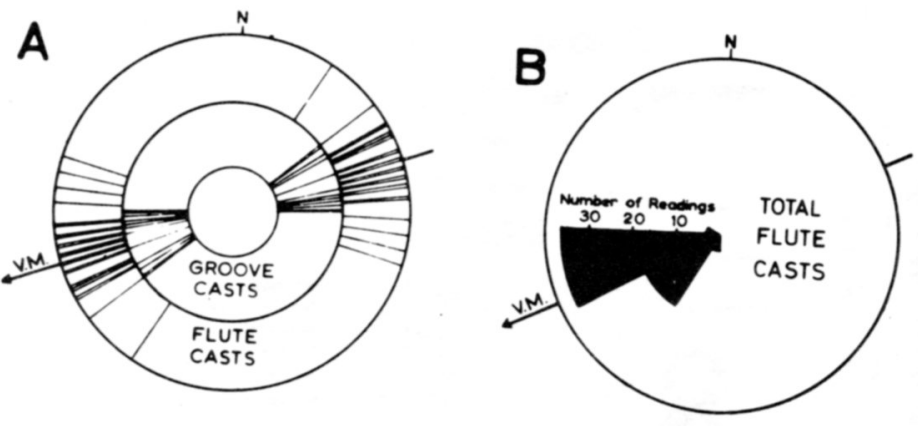

Fig. 6. Paleocurrent directions from the Escuminac Formation west of Miguasha Wharf (from Dineley and Williams, 1968a). V.M. - vector mean: (A) $250^{\circ}$ for groove casts (41 readings), (B) $244^{\circ}$ for flute casts (61 readings). Angular interval on rose diagram: $30^{\circ}$.

layers, quartz, and minor plagioclase. Heating of the samples at $600^{\circ} \mathrm{C}$ for one hour showed the absence of kaolinite. The chlorites tend to be iron-rich, on the basis of their strong even basal reflections (002) and (004) compared to the odd reflections (001), (003), and (005) (Brindley, 1972). Illite crystallinity (IC) values, expressed as $\Delta^{\circ} 2 \theta$ [difference in angular position of the (001) peak flanks at half-height] for the Escuminac Formation, range from 0.32 to 0.60 and show regular variation from bottom to top of the formation. In the lower $30 \mathrm{~m}$, values from 0.32 to $0.46 \Delta^{\circ} 2 \theta$ were found; in the interval from 66 to $103 \mathrm{~m}$, values (of six samples) range from 0.47 to $0.60 \Delta^{2} 28$.

Reflectance measurements could not be carried out on the same samples which were used for IC, because the shales did not contain sufficient particulate organic matter for statistically meaningful reflectance determinations. Therefore, reflectance was measured on coalified plant fragments and dispersed organic particles in sandstone and laminite samples, respectively. Four samples from the Escuminac Formation were studied for reflectance under oil, which, from top to bottom in the type section, gave the following results:

$$
\begin{gathered}
\text { mean random reflectance } \\
\text { under oil } R_{o} \text { in } \%
\end{gathered}
$$

Uppermost thick sandstone at $112 \mathrm{~m}$ level: vitrinite

Channelized sandstone at $90 \mathrm{~m}$ level: vitrinite

Laminite at $55 \mathrm{~m}$ level: dispersed organic matter

Sandstone at $33 \mathrm{~m}$ level: dispersed organic matter

These values fall within the oil window and correspond to the middle diagenetic zone. Reflectance values measured on different macerals are not directly comparable. The number of measurements is too small to warrant any interpretation in terms of maximum burial temperatures. Spores from the Escuminac Formation show a light-brown color in transmit- ted light (M. Arsenault, personal communication) which corresponds to a vitrinite reflectance range of 0.6 to $0.9 \%$ (Heroux et al., 1979). Comparison with other thermal maturation studies in post-Acadian intramontane successor basins of the Maritime Provinces shows a wider range in reflectance values in those basins; whether measured either directly (0.75-1.91\% for the Lower Carboniferous Deer Lake Basin in Newfoundland, Hyde et al., 1988) or determined from thermal alteration indices (TAI) based on spore coloration ( 0.5 $3.0 \%$ for the Lower Carboniferous Horton Group in the Fundy Rift Basin of Nova Scotia, Utting and Hamblin, 1991). That range reflects, among other factors, asymmetrical subsidence.

Illite crystallinity values for the Escuminac Formation would indicate a higher diagenetic grade than vitrinite reflectance, including some anchizonal values $(<0.42 \quad \Delta 2 \theta)$. However, reflectance is generally considered more reliable for the determination of grade and suggests that alteration did not exceed the middle diagenetic stage or a few kilometres (maximum 3-4 km) of burial, assuming a normal continental geothermal gradient. This amount of subsidence and burial was in all likelihood achieved in post-Devonian time after the Acadian orogeny. That diagenesis was affected by burial rather than contact metamorphism or tectonism has been established by a regional illite-crystallinity study of Gaspe Peninsula (Hesse and Dalton, 1991). However, the strong IC gradient observed in the Miguasha section $\left(0.28 \Delta^{2} 28 / 100\right.$ $\mathrm{m})$ suggests lateral migration of subsurface fluids of special chemical composition (potassium-rich fluids to promote illitization). These may have affected the bottom part of the formation more intensely than the rest, or the bottom part only, because the difference in burial depth between bottom and top of the formation is insufficient to explain the gradient. If the temperature of the fluids corresponded to burial depth, they would not have caused oxygen-isotope anomalies. These interpretations should be considered tentative because of the limited number of analyses.

\section{LITHOSTRATIGRAPHY}

The Escuminac Formation has been subdivided into six fossil "zones" by Russell (1939) which are actually zones of fossil occurrence indicated on Figure 7. Dineley and Williams (1968a) recognized five lithostratigraphic units (Fig. 8b). We are presenting here (Fig. 7) a more detailed lithostratigraphic subdivision into eight units based on sandstone:shale ratio in the detailed measured type-section west of Miguasha Wharf (Table 3). In this section, cross-laminated sandstone of the Escuminac Formation overlies with sharp contact cobble to boulder conglomerate of the Fleurant Formation (Fig. 9).

Unit 1 comprises the basal $32 \mathrm{~m}$, ending $2 \mathrm{~m}$ above marker bed \#8 and including Russell's (1939) lower two fossil zones. Sandstones up to $1 \mathrm{~m}$ thick occur at the base. At the top of the lower third of the sequence, thinner sandstone beds contain ellipsoidal concretions. Concretions in the shales 


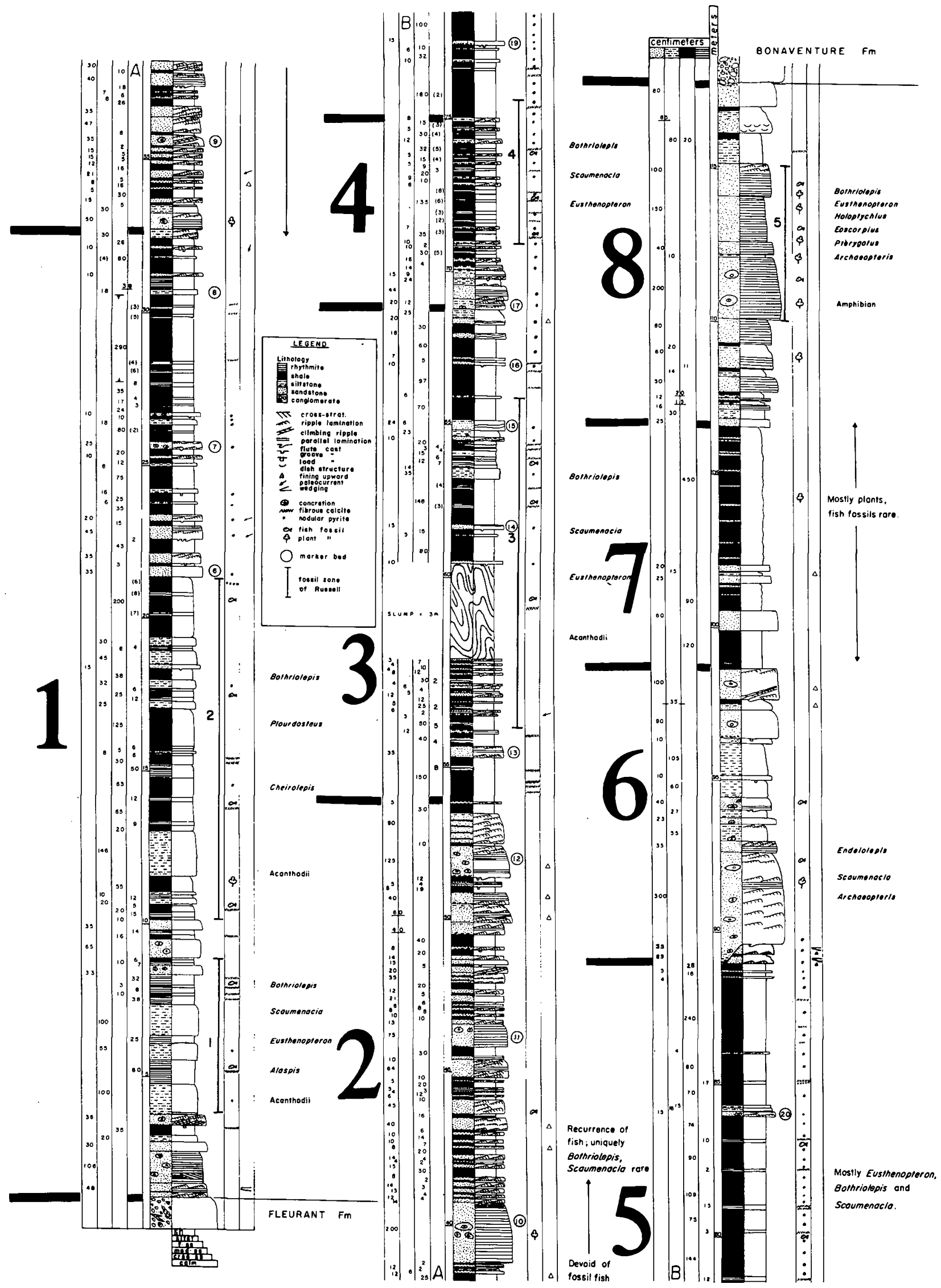

Fig. 7. Detailed section of the Escuminac Formation, seacliffs west of Miguasha Wharf (from Hesse and Sawh, 1982). The numbers to the left of each column refer (from left to right) to the thickness of sandstone, siltstone and shale beds, laminites (rhythmites), and cumulative thickness of the section from ( $1 \mathrm{~m}$ below) the base, respectively. Bold numbers between horizontal lines: range of lithologic units 1 to 8 . 


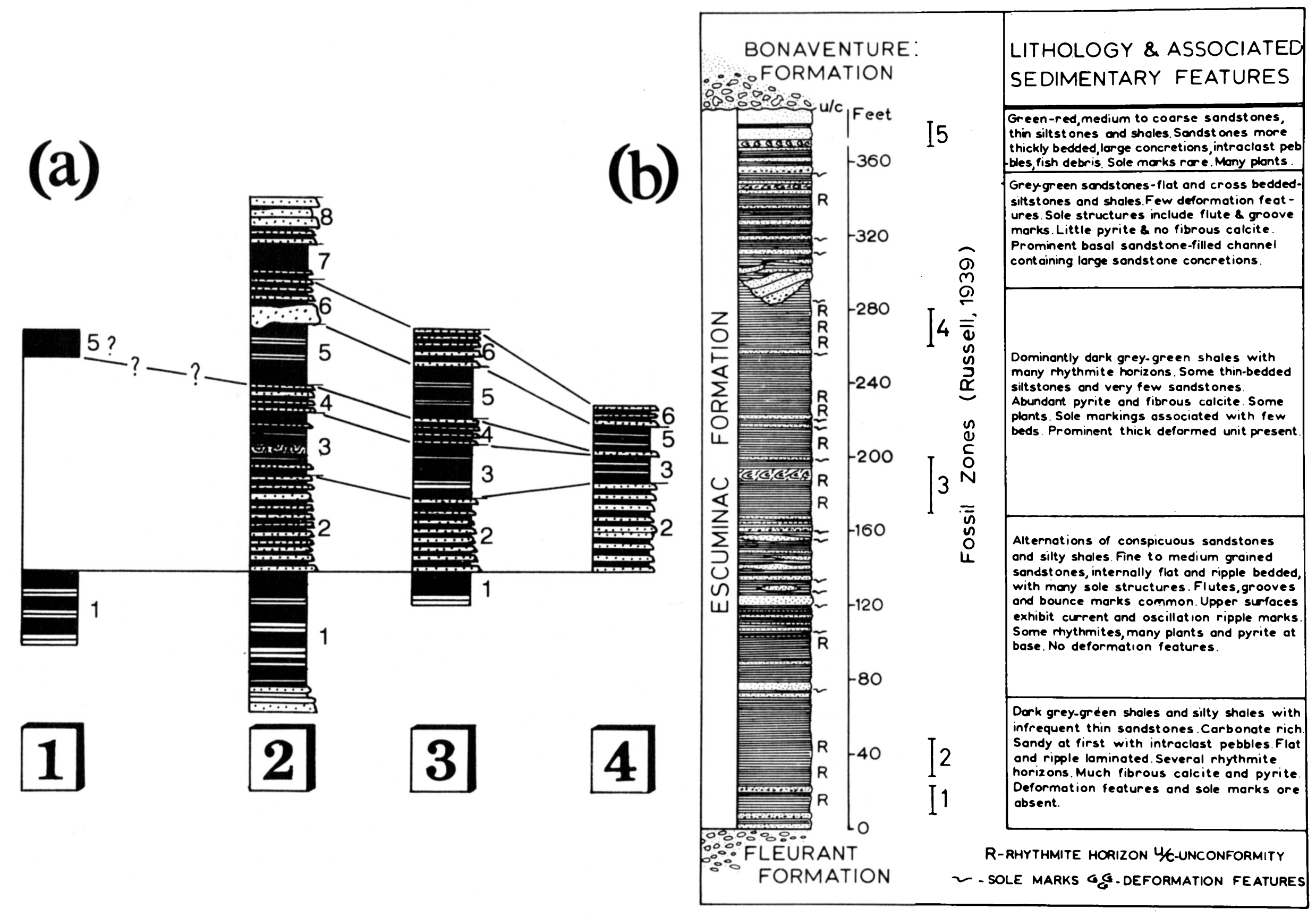

Fig. 8. Lithostratigraphic subdivisions of the Escuminac Formation: (a) present study (for outcrop localities 1 to 4 see Figure 2); (b) Dineley and Williams (1968a). 
Table 3. Sandstone and shale thicknesses and thickness ratios for the lithologic sequences of the Escuminac Formation.

\begin{tabular}{lrcc}
\hline & $\begin{array}{c}\text { Sandstone } \\
\text { thickness } \\
\text { Sequence }\end{array}$ & $\begin{array}{c}\text { Shale } \\
\text { (hickness } \\
\text { (in m) }\end{array}$ & $\begin{array}{c}\text { Sandstone/Shale } \\
\text { thickness ratio }\end{array}$ \\
\hline & & & \\
1 & 12.29 & 19.30 & 0.64 \\
2 & 15.39 & 5.35 & 2.88 \\
3 & 2.95 & $\left.9.48^{*}\right)$ & 0.31 \\
4 & 2.98 & 3.37 & 0.88 \\
5 & 0.88 & 14.73 & 0.06 \\
6 & 6.93 & 1.97 & 3.57 \\
7 & 3.30 & 4.85 & 0.68 \\
8 & 8.24 & 1.31 & 6.29 \\
\hline
\end{tabular}

*) without slump horizon

are flat and disk shaped. At the base of the upper third, sandstones with climbing ripple cross-lamination, parallel lamination and flute and groove casts are common. A $1.5 \mathrm{~m}$ thick homogeneous shale between 10 and $15 \mathrm{~m}$ may be a mudturbidite. The sandstone:shale ratio is 0.64 . The fine-grained rocks include at various levels in the unit thin layers of laminite. The location of fibrous calcite layers, pyrite nodules and fish and plant fossils is indicated in Figure 7. Among the fish fossils are Alaspis, Plourdosteus, Bothriolepis, Homalacanthus, Triazeugacanthus, Miguashaia, and Cheirolepis.

Unit 2 spans the interval from 32 to $53 \mathrm{~m}$ of the vertical profile, including marker bed \#12 at the top. It is sandstonerich (sandstone:shale ratio of about 3 ). Individual sandstone beds are up to $2 \mathrm{~m}$ thick and parallel laminated and ripplecross laminated (including abundant climbing ripple-cross lamination). Many show graded bedding and an abundance of plant fragments. Shales in this sequence do not comprise laminites and no fish fossils have been found from the base up to $41 \mathrm{~m}$. At the top, between marker beds $\# 10$ and 11 , Bothriolepis and rare Scaumenacia occur.

Unit 3. This shale-dominated unit (sandstone:shale ratio of 0.3 ) covers the stratigraphic interval from 53 to $68 \mathrm{~m}$ and encompasses Russell's fossil zone 3. Thin laminite layers are mostly associated with fibrous calcite, which also occurs in the homogeneous shale. The unit includes a prominent $3 \mathrm{~m}$ thick slump horizon between 57 and $60 \mathrm{~m}$, which displays intense syngenetic folding strikingly similar to deformation features described from some classical subaquatic slump localities (e.g., Gregory, 1969, Fig. 4). The slump contains deformed fibrous calcite layers which do not cross-cut bedding, supporting their early diagenetic origin. Thin, finegrained sandstone-siltstone turbidites are intercalated throughout the sequence. Among the fossil fish, Scaumenacia is most abundant, followed by Bothriolepis, Eusthenopteron and some acanthodians.

Unit 4 spans the short interval from 68 to $74 \mathrm{~m}$, begin-

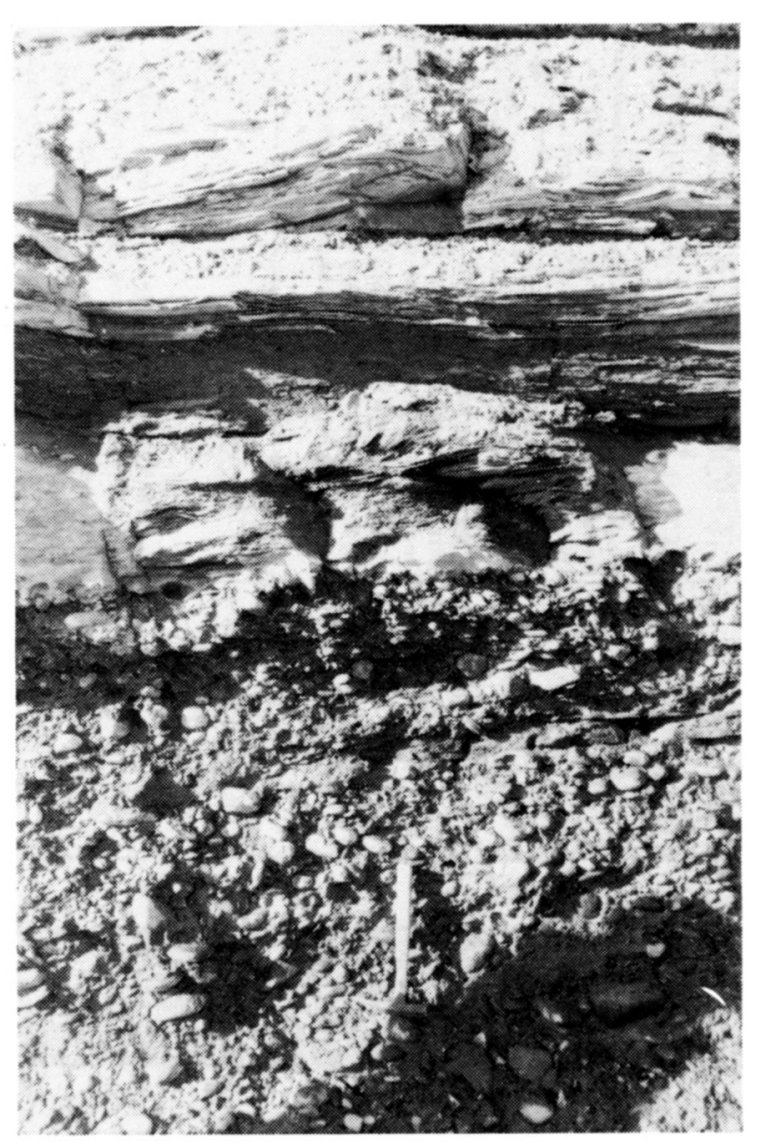

Fig. 9. Sharp stratigraphic contact between Fleurant Formation (pebble and cobble conglomerate) and overlying Escuminac Formation (ripple cross-laminated, wavy and parallel laminated and cross-bedded sandstone) at locality 2, about $400 \mathrm{~m}$ west of Miguasha Wharf.

ning with marker bed \#17. It is roughly equivalent to Russell's fossil zone 4 which contains Bothriolepis, Scaumenacia, and Eusthenopteron. It includes abundant sandstone-siltstone turbidites (sandstone:shale ratio of 0.9 ) which become thinner bedded towards the top. Thin layers of laminite are associated with fibrous calcite.

Unit 5 between 74 and $88 \mathrm{~m}$ is shale dominated (sandstone:shale ratio of 0.06 ). Numerous fibrous calcite layers and a few sandstone turbidites not exceeding $15 \mathrm{~cm}$ in thickness are intercalated in the shales. Marker bed $\# 20$ contains carbonate concretions. Fish fossil horizons containing Eusthenopteron, Scaumenacia, and Bothriolepis occur immediately below this bed.

Unit 6 from 88 to $98 \mathrm{~m}$ is another sandstone-rich unit (sandstone:shale ratio of 3.6), starting with a thin sandstone bed whose thickness rapidly changes laterally and thickens westwards to $3 \mathrm{~m}$. Where it is thickest, it contains shale clasts at its base and pyrite nodules. It is probably a channel that has eroded thinner underlying beds at its base (Fig. 4d). Large calcite-cemented concretions occur throughout the bed. Parallel and cross-lamination are present in the upper three quarters of this bed. Laminites and fibrous calcite are absent in unit 6. Pyrite is concentrated at its base where the well- 
preserved plant fossil Archeopteris also occurs. Fragments of Bothriolepis are locally abundant in the sandstone, but wellpreserved specimens such as Scaumenacia and Endeiolepis are restricted to concretions.

Unit 7 between 98 and $106 \mathrm{~m}$ is shale-rich (sandstone:shale ratio of 0.65 ). It contains a few sandstone interbeds. It is free of laminites and pyrite and contains mostly plant fossils; fossil fish are rare.

Unit 8 from 106 to $117 \mathrm{~m}$ at the top of the section is not easily accessible and is overlain by the Bonaventure Formation. It comprises Russell's fossil zones 5 and 6 which contain Bothriolepis, Scaumenacia, Eusthenopteron, Holoptychius, Elpistostege watsoni, the arthropods Eoscorpius and eurypterids as well as the plant fossil Archeopteris. The sequence is sandstone-dominated with a sandstone:shale ratio of 6 . Individual sandstone beds are up to $2 \mathrm{~m}$ thick and contain large concretions. Grain-size is medium to coarse sand. In this sequence, red colours replace the greenish-gray of the lower sequences. This appears to be a staining effect from the red beds of the overlying Bonaventure Formation (Russell, 1939), although Alcock (1935) ascribed the red colour to oxidation during weathering in Carboniferous time, prior to deposition of the Bonaventure because he did not find it associated with other formations immediately underlying the Bonaventure Formation. However, the Silurian carbonate succession at Quinn Point on the south side of Chaleurs Bay in New Brunswick clearly is stained red from the overlying Bonaventure Formation, supporting Russell's view.

Units 7 and 8 are absent in sections (3) east of Miguasha Wharf and (4) at Yacta Point, where denudation below the Bonaventure Formation has cut deeper into the Escuminac Formation. The angular unconformity between the Bonaventure and the Escuminac is best exposed in the section east of the wharf, where large blocks of Escuminac sandstone occur reworked in the basal Bonaventure conglomerate (Fig. 5c).

\section{Depositional Environment}

Two contrasting views concerning the paleoenvironment of deposition of the Escuminac Formation have emerged from the literature: (i) a lacustrine origin, advocated by Dineley and Williams (1968a,b), Carroll et al. (1972), Hesse and Sawh (1982), and Rust et al. (1989) on the basis of sedimentological and paleogeographic considerations; and (ii) a marine or coastal marine setting favored by Schultze (1972), Schultze and Arsenault (1985), and Vézina (1991) on the basis of palecological arguments. A third view is a compromise between the former two and envisages a brackish environment (Schultze and Arsenault, 1985). It is based on geochemical evidence (Chidiac, 1989) and is modified in the present study, which specifically suggests an estuarine setting for the Escuminac.

Arguments to be taken into consideration in this debate comprise sedimentologic, paleogeographic, paleontologic and geochemical evidence, but unfortunately, none has so far provided unequivocal, ultimately conclusive proof for any single one of the hypothetical environments.

\section{Lacustrine environment}

Turbidite deposition in modern (Chikita, 1990; Chikita and Okumura, 1990; Gould, 1951; Lambert et al., 1984; Nelson et al., 1986; Siegenthaler et al., 1987; Sturm and Matter, 1978) and ancient lakes (Dyni and Hawkins, 1981; Link and Osborne, 1978; Reineck and Weber, 1983) is a well established phenomenon; in fact the first reported observation of turbidity currents is from a lacustrine environment, i.e., Lake Geneva in Switzerland (Forel, 1885, 1888). Deep lake basins form suitable receptacles for turbidites. The formation of undercurrents from sediment-laden river water poses less of a problem in freshwater lakes than it does in the marine environment. The density difference between fresh and saltwater makes the direct transformation of turbid river water into turbidity currents impossible in most marine situations and leads to intermittent deposition in prodelta and open shelf environments in a non-turbidite, hemipelagic fashion. The generation of turbidity currents requires transport of the sediment into a position (e.g., at the shelf edge or into the head of a submarine canyon on the shelf) suitable for remobilization by turbidity-current triggering events. While lacustrine turbidite deposition is a feasible and efficient sedimentation mechanism, the sedimentary structures of the current-deposited Escuminac clastics only prove their turbidite origin but not the lacustrine environment.

Support for a continental setting of the Escuminac Formation comes from its stratigraphic association with fluvial sequences below and above, i.e., the Fleurant Formation representing a proximal, gravel-dominated braidplain environment, and the Bonaventure Formation which consists of alluvial-fan and braided- to meandering-river deposits (Zaitlin, 1981). Although the latter is separated from the Escuminac by a major unconformity, it shows that marine conditions most likely were not reestablished after the Acadian orogeny. This association makes a lacustrine environment plausible, but in itself does not provide conclusive evidence either, especially because of the hiatuses between the formations.

Laminites indicative of periodically stagnant bottom water are also well compatible with a lacustrine environment. Laminites with carbonate-rich light laminae in particular have been attributed to inorganic calcite precipitation in fresh or brackish-water lakes during the summer, when dissolved $\mathrm{CO}_{2}$ of the surface waters is reduced and $\mathrm{pH}$ increased as a result of elevated temperature and phytoplankton activity. This may lead to strong supersaturation of the surface waters with respect to calcite solubility (Kelts and Hsü, 1978). If the calcite-rich light laminae are not detrital in origin, they would then represent the summer deposit of seasonal couplets, i.e., true varves. The organic-matter and clay-rich dark counterpart forms during the fall, winter and spring. Preservation of the laminae, as mentioned before, indicates absence of bottom-living organisms because of stagnant, oxygendepleted bottom waters which are encountered in many stratified lakes. 
Taken together, the sedimentologic lines of evidence discussed so far seem to provide a coherent picture for the Escuminac Formation, which could most easily be satisfied by a lake model. Based on the merits of this model, the junior author (Sawh, 1982) suggested a seven-stage evolutionary history of the Escuminac Lake in Late Devonian time.

Stage 1 represented the initial phase of lake basin formation, possibly after some time of denudation of the Fleurant surface into a flat-levelled peneplain. The sharp contact between the Fleurant Conglomerate and the basal sandstones of the Escuminac Formation might be a disconformity, but more likely the dip of sand lenses in the conglomerate, the only structural feature seen in the Miguasha section, is depositional representing large-scale braid-bar cross-stratification. Cross bedding (Fig. 9) is also present in one of the two basal sandstone beds of the Escuminac Formation, possibly indicating proximal turbidite deposition rather than a fluvial environment.

Stage 2 began with the first appearance of laminites some $5 \mathrm{~m}$ above the base of the formation, indicating that rapid deepening of the basin had occurred and allowed for the development of a body of stagnant water below a thermo- or pycnocline. Turbidity currents of at least medium-density carried medium to very fine sand to greater basin depth. Lowdensity turbidity currents carrying only silt and clay-sized components also began to fill the basin. They required fresh or low-salinity brackish water in the receptor basin because they could not break through seawater of normal salinity. Stages 1 and 2 comprised unit 1 .

Stage 3 corresponds to unit 2 with an abundance of sandstone turbidites indicative of increased activity of the source areas, either because of intensified uplift or increased runoff. Stagnant conditions did not develop in the basin at this stage either because of frequent renewal of bottom water by oxygen-rich river-derived turbidity currents (for a modern example see Lambert et al., 1984) or due to a temporary change in climate (less likely).

Stage 4 signalled a return to periodically stagnant conditions by the presence of laminites. It comprises units 3 to 5 . Both units 3 and 4 show an overall thinning-upward and fining-upward trend of their turbidite successions, possibly related to source-area control; in unit 5 very few turbidity currents reached the basin floor.

Stage 5 saw a massive influx of sand, possibly indicating progradation of the main feeder channel to the basin floor (unit 6) and concomitant basin filling, again in the absence of laminites.

In Stage 6, non-stagnant bottom-water conditions prevailed even in the absence of a strong supply of sand (unit 7), possibly suggesting that the basin had become too shallow for the development of a thermocline because of the rapid infill that had taken place before and exceeded the rate of subsidence.

Stage 7. In this terminal stage, infilling of the basin continued by sandstone turbidites which are most proximal in character (unit 8) of all units of the entire section.

This proposed evolutionary history for the postulated lake basin probably concerns only the deepest part of the lake, i.e., its basin plain. It shows an overall trend of basin deepening, arrival of a (major?) channel, followed by shallowing after rapid infilling. Stratification of the water column led to recurrent short intervals of bottom-water stagnation. None of the extensive shallow-water lacustrine facies described from other ancient lacustrine formations (e.g., Link and Osborne, 1978) is preserved in the Escuminac Formation.

\section{Coastal marine environment}

Important information on the depositional environment of the Escuminac Formation is contained in its fossil fauna. Interpretation of the organisms' habitat includes some conflicting evidence. Most striking is the complete absence of any shelly invertebrate fauna, which would be unexpected for any fully marine open-shelf or even near-shore deposits of this age (Goldring and Langenstrassen, 1979). This is negative evidence against an open marine environment and indirectly in favor of a lacustrine or partly restricted, marginal marine paleoenvironment. Notable also is the absence of conodonts and other marine microfossils such as chitinozoans and acritarchs, but their lack may be facies controlled.

As has already been pointed out by Schultze (1972) and Schultze and Arsenault (1985) however, the fish fauna contains elements which have also been described from brackish or marine environments. The fish specimens show two distinct modes of preservation. Those preserved in mudrocks are flat and compressed, whereas those found in sandstone turbidites are often disintegrated reflecting the turbulent conditions of their way of entombment. Some specimens, however, are not broken up and are bodily preserved. Rapid burial in turbidites and early cementation, particularly in carbonate concretions in the sandstone, preserved their shape in three dimensions. The shales and laminites, on the other hand, were subject to considerable water loss and compaction during burial that caused compression. A specimen on display in the Museum at Miguasha shows three individuals of Bothriolepis within a ripple-cross laminated turbidite division, all oriented parallel, heads pointing up-current (Fig. 5d). The message encoded in the picture seems to be obvious: swimmers trapped in a Devonian turbidity current struggling for survival but with no chance of success-or is this a thanatocoenosis?

Carroll et al. (1972) suggested that the fish belonged to three ecologically different groups:

(1) Open or mid-water nekton: The acanthodians, the early palaeoniscoid Cheirolepis, some Crossopterygii and possibly anaspids. Devonian Acanthodii and Anaspida were dominantly freshwater inhabitants (Colbert, 1980; Denison, 1979; Westoll, 1979), although some of the latter could tolerate brackish water. The crossopterygians Holoptychius and Eusthenopteron have also been reported from marine strata (Thomson, 1969).

(2) Near-shore or fluvial benthos: The Osteostraci and Arthrodira were probably bottom dwellers, feeding on bot- 
tom sediments, consuming algae or other microphagous food. Other fish such as Bothriolepis also lived in this habitat, but were not confined to it. Osteostraci were freshwater forms (Westoll, 1979). Genera with universal distribution, on the other hand, most likely were also capable of inhabiting the marine environment, including Bothriolepis, the arthrodire Plourdosteus, the already mentioned Eusthenopteron, and Cheirolepis whose scales are often found together with conodonts (Schultze, 1972).

(3) Benthos of mudflats and other shallow areas subject to drought: The presence of lungfish and Crossopterygii and the tetrapod-related Elpistostege suggests such a habit nearby, although it is not preserved in the exposed sections. Bothriolepis was probably capable of surviving in this environment as well.

In each of these faunas there were microphagous feeders and predators while the lungfish may have been omnivorous, eating plants or animal prey as inclined. Cheirolepis must have been the most formidable predator in the open water and perhaps the best swimmer. The acanthodians were perhaps also predatory. Eusthenopteron was a predator among the crossopterygians (Arsenault, 1982). Plourdosteus was, no doubt, the most notable, though sluggish predator among the benthos (Carroll et al., 1972, p. 93).

In the most recent palecological analysis of the ichthyofauna of the Escuminac Formation, Vézina (1991) and Schultze and Cloutier (in press) compared it with marine Middle and Late Devonian fish faunas from different localities of the world and came to the conclusion that a coastal marine environment would best suit the faunal assemblage, supporting earlier views by Schultze (1972) and Schultze and Arsenault (1985).

\section{Brackish water environment}

New evidence has been provided by a recent geochemical and isotopic study (Chidiac, 1989). Alerted by the high concentrations of nodular or disseminated pyrite at certain stratigraphic levels (Fig. 4c) in the Escuminac Formation, which require a large reduced sulfur reservoir most easily available from bacterial reduction of seawater sulfate, this author challenged the lacustrine hypothesis. Although it is true that non-marine deposits are generally poor in pyrite, just how much pyrite can form in an organic-matter rich lacustrine setting from the bacterial decomposition of organic matter has not been quantified. Chidiac instead used oxygen and carbon isotopes of the laminites, fibrous calcite, and carbonate concretions, and boron concentrations and boron isotopic ratios of shales. The oxygen and carbon isotopic analyses basically prove the early diagenetic derivation of carbon in the concretions and fibrous calcite from organic-matter decomposition during methanogenesis, as had been postulated by Hesse and Sawh (1982). The oxygenisotopic composition of some of the calcite in the light laminae of the laminites would be compatible with direct inorganic precipitation from surface water. However, it is not possible to distinguish isotopically between precipitation from seawater or freshwater, because Chaleurs Bay in Devonian time was located close to the equator (at $12^{\circ} \mathrm{S}$ according to Woodrow et al., 1973 and Habicht, 1979, although paleogeographic reconstructions by Heckel and Witzke, 1979 and Streel et al., 1990 suggest a more southerly paleoposition near $30^{\circ}$ S), where meteoric water has approximately the same oxygen-isotopic composition as seawater.

What is significant, however, are the results of boron analyses. The $B$ concentrations (with a mode between 50 and $60 \mathrm{ppm}$ and a mean between 70 and $80 \mathrm{ppm}$ ) are too high for freshwater and too low for normal seawater and thus suggest a brackish environment (Chidiac, 1989). The measured boron isotope ratios seem to be in line with this conclusion. An open question remains, however, as to what extent the boron content of the clays may have been inherited from detrital, older marine, clayey sedimentary rocks. For this question to be tackled, detailed radiometric studies of the Escuminac shales are required, because $\mathrm{K}-\mathrm{Ar}$ as well as $\mathrm{Rb}-\mathrm{Sr}$ and $\mathrm{Nd-}$ $\mathrm{Sm}$ isotope systematics can provide insight concerning the amounts of clay components inherited from previous environments that have not been affected by diagenesis or weathering.

\section{Estuarine environment}

The most likely depositional paleo-environment which accommodates best the different lines of evidence is probably an estuary. It would be compatible with (i) an ichthyofauna with certain marine affinities, (ii) total lack of a shelly marine invertebrate fauna, (iii) temporarily stagnant conditions, (iv) a relatively deep trough suitable as a receptacle for turbidites, (v) boron concentration and isotopic composition indicative of brackish-water deposition, and (vi) stratigraphic association with fluvial sequences above and below. The lack of shelly invertebrate remains could be due to the combined effects of lowered salinity and high turbidity in an estuary. Stagnant conditions in an estuary, although they affected only a small fraction of the total time of deposition in the Escuminac, would require either a silled lagoonal estuarine basin or an open-ended estuary (Reinson, 1992, p. 183). In such a setting, temporary and/or local variations in salinity could be a control on the frequency, local distribution and composition of turbidites, because during times of elevated salinity, turbidity currents, particularly low-density currents, could probably not break through the salt wedge and would spread out as mid-water interflows or turbid surface plumes. A silled estuary would have a general basin shape comparable to that of a lake, except that it had a connection to the open sea. The seven stages of basin evolution outlined above for the Escuminac Lake would be equally applicable to an Escuminac estuary. Sea-level fluctuations of proper periodicity and magnitude, if they occurred, could have periodically changed a silled estuary into a lake. 


\section{Discussion}

None of the evidence provided is entirely convincing for any of the different alternative paleoenvironments that have been proposed for the Escuminac Formation. The basic reason for this is the very limited exposure area, which does not provide sufficiently stringent constraints for any one hypothesis. With the information available, any honest environmental interpretation must allow for possible alternatives.

The sedimentologic and paleogeographic evidence for the lake remains indirect. Paleontologic-palecological arguments for a marine or brackish setting are inferential and equivocal. Close relatives of the species which are quoted as marine inhabitants also lived in freshwater lakes. The geochemical evidence is not as strong as it may look at first sight, because of the problem of inherited signatures. The estuarine setting, finally, faces the paleogeographic dilemma that Chaleurs Bay is some $800 \mathrm{~km}$ away from the nearest known marine Upper Devonian strata in the submarine part of the Catskill delta in New York State (Sutton et al., 1970) and several hundred kilometres from the possible southern paleoshoreline of the Old Red Continent (in Morocco?, Fig. 10). On the other hand, the evidence presented here in favor of an estuary may help to redefine the boundaries of the Old Red Continent. However, if the presently accepted outline of the Old Red Continent (Fig. 10) is used as a basis for discussion, its shorelines would have had to undergo vast lateral shifts due to sea level fluctuations, or else the estuary would have had enormous dimensions, comparable to the modern Gulf of St. Lawrence, in order to join the nearest ocean, and yet it left almost no trace in the geologic record. The nearest Upper Devonian rocks in southern New Brunswick and adjacent Maine (Famennian Perry Formation) are continental in origin (Schluger, 1973), and the overall evolution of the Acadian orogen, discussed in the introduction, led to progressive regional emergence since late Early to early Middle Devonian time. However, the Late Devonian was a time of considerable vertical and horizontal crustal movement that extended into the Carboniferous, as shown by extensive intermontane successor-basin and asymmetrical strike-slip half-graben development in the Maritime Provinces. If seen in this context, the Escuminac Formation is by no means an isolated occurrence of Late Devonian continental deposition. The various Late Devonian-Early Carboniferous basins in Newfoundland, Nova Scotia and the intervening offshore areas in the Gulf of St. Lawrence contain a large variety of sedimentary facies of mostly fluvial red-bed sequences, lacustrine black shales and marginal marine evaporite and carbonate deposits. These include the Bay St. Georges Basin (Knight, 1983), the Deer Lake Basin (Hyde et al., 1988), the Ainslie, Windsor, and Moncton sub-basins of the Fundy Rift Basin (Hamblin and Rust, 1989), and the St. George Basin or Cabot sub-basin of Marillier et al. (1989) and Hamblin and Rust (1989), respectively, although many of these are somewhat younger than the Escuminac.

A possible modern-day tropical analog for the Escuminac Formation would be Kau Bay in Indonesia, which receives its

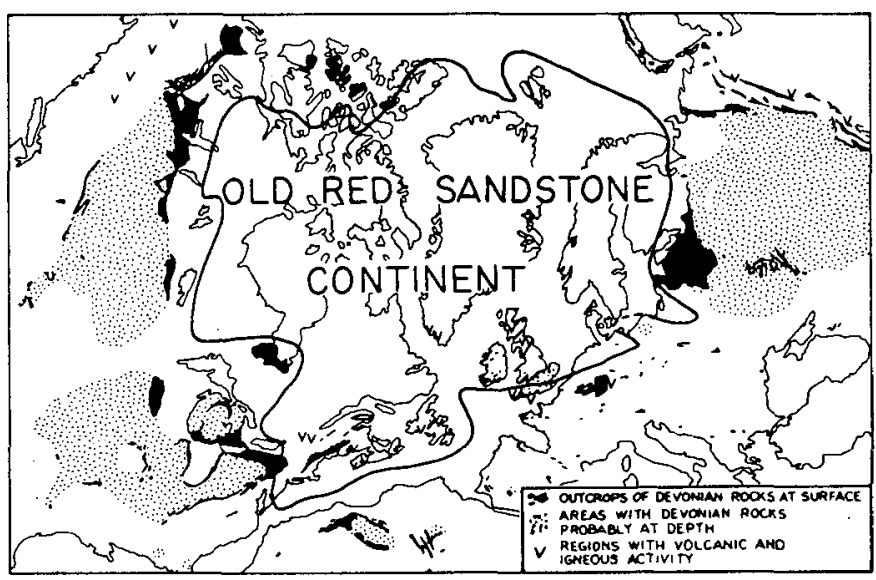

Fig. 10. Approximate outline of the Old Red Continent produced by the collision of the North American and Eurasian landmasses (from Dineley, 1975).

main river runoff from the Kau river and was cut off from the surrounding seas during Pleistocene low sea-level stands, because its sill is only $40 \mathrm{~m}$ deep (Middelburg, 1990). It is surrounded by broad shelf areas with mangrove swamps and sandy beaches. Its steep slopes are dissected by submarine canyons through which shallow water sediments are funneled by mass-flow transport mechanisms to the $470 \mathrm{~m}$ deep basin floor. This $60 \times 30 \mathrm{~km}$ wide silled basin qualifies as an estuary in the sense of the definition ("the seaward end of a river valley where fresh water comes into contact with seawater"; Bates and Jackson, 1980). As a modern analog, its tectonic setting in an active volcanic-island arc would only fit the subduction-collision model for the Acadian orogeny, but not the strike-slip tectonic model. The most recent definition of an estuary by Dalrymple et al. (1992) as "the seaward portion of a drowned valley system which receives sediment from both fluvial and marine sources and which contains facies influenced by tide, wave and fluvial processes" does not consider man-flow processes, although fluvial "sand and/ or gravel" deposition "at the head of the estuary" would easily lead to redeposition, if slope gradients leading to a central basin were steep enough.

On a larger scale, marginal seas like the Baltic Sea or Hudson Bay display the right kind of estuarine circulation that includes them in the definition of estuarine water bodies ("a portion of an ocean, as a firth or an arm of the sea, affected by freshwater", alternative definition in Bates and Jackson, 1980). This type of circulation can lead to temporary stagnation, although the setting of these basins in temperate humid or boreal climates differs from that under which the Escuminac Formation formed. For the same reason, fjords do not represent suitable analogs.

\section{Acknowledgements}

This research was supported by operating grants from the Natural Sciences and Engineering Research Council of Canada to the senior author. Critical reviews and suggestions for improvements by M. Gibling, C.W. Stearn, B. Zaitlin and an 
anonymous reviewer, editorial comments by $\mathrm{G}$. Williams and paleontological information by H.P. Schultze are greatly appreciated.

Alcock, F.J. 1935. Geology of the Chaleur Bay region. Geological Survey of Canada, Memoir, 183 p.

ArNold, C.A. 1936. Observation on fossil plants from the Devonian of eastern North America. Contributions from the Museum of Paleontology, University of Michigan, 5, pp. 37 56.

Arsenault, M. 1982. Eusthenopteron foordi, a predator on Homalacanthus concinnus from the Escuminac Formation, Miguasha, Quebec. Canadian Journal of Earth Sciences, 19. pp. 2214-2217.

BATES, R.L. and JACKsON, J.A. 1980. Glossary of geology, second edition. American Geological Institute, 749 p.

BéDARD, J.H. 1986. Pre-Acadian magmatic suites of the southeastern Gaspé Peninsula. Geological Society of American Bulletin, 97, pp. 1177-1191.

Béland, P. and Arsenault, M. 1985. Scauménellisation de l'Acanthodii Triazeugaganthus affinis (Whiteaves) de la Formation d'Escuminac (Dévonien Supérieur de Miguasha, Québec): révision du Scaumenella mesacanthi Graham-Smith. Journal Canadien de Science de la Terre, 22, pp. 514-524.

Bourque, P.A., Laurent, R., and St-Julien, P. 1985. Acadian wrench faulting in southern Gaspe Peninsula, Québec Appalachians. Geological Association of Canada, Annual Meeting, Fredericton, Program with Abstracts, 10, p. A6.

Bourque, P.A., Brisebois, D., and Malo, M. 1989. Middle Paleozoic rocks of Québec and adjacent New Brunswick. In The Appalachian/Caledonian region: Canada and Greenland. Edited by H. Williams. Geological Society of America, Decade of North American Geology, F-1.

BradLEY, D.C. 1983. Tectonics of the Acadian orogeny in New England and adjacent Canada. Journal of Geology, 91, pp. 381-400.

Brideaux, G.W. and Radporth, N.W. 1970. Upper Devonian miospores from the Escuminac Formation, eastern Quebec. Canadian Journal of Earth Sciences, 7, pp. 29-45.

BrindleY, G.W. 1972. Chlorite minerals. In The X-ray identification and crystal structure of clay minerals (second edition). Edited by G. Brown. Mineralogical Society of London, pp. 242-296.

Carroll, R.L., Belt, E.S., Dineley, D.L., Baird, D., and McGREGOR, D.C. 1972. Vertebrate paleontology of eastern Canada. Guidebook, Excursion A59, 24th International Geological Congress, Montreal, $113 \mathrm{p}$.

Chidiac, Y. 1989. Analyse du paléoenvironnement de la Formation d'Escuminac (Dévonien supérieur), Miguasha, Québec, dans le contexte des données sédimentologiques, paleontologiques et geochimiques. Thèse de la maitrise en sciences de la terre, Université du Québec à Montréal, $130 \mathrm{p}$.

ChIKITA, K. 1990. Sedimentation by river-induced turbidity currents: field measurements and interpretation. Sedimentology, 37, pp. $891-905$.

Chikita, K. and Okumura, Y. 1990. Dynamics of turbidity currents measured in Katsurazawa Reservoir, Hokkaido, Japan. Journal of Hydrology, 117, pp. 323-338.

ColBerT, E.H. 1980. Evolution of the vertebrates, third edition. John Wiley and Sons, $510 \mathrm{p}$.

DalRYMPLE, R.W., Zaitlin, B.A., and Boyd, R. 1992. Estuarine facies models: Conceptual basis and stratigraphic implications. Journal of Sedimentary Petrology, 62, pp. 1030-1046.

Denison, R. 1979. Acanthodii. Handbook of Paleoichthyology, 5 , G. Fischer Verlag, 62 p.

DingleY, D.L. 1975. North Atlantic Old Red Sandstone - some implications for Devonian paleogeography. In Canada's continental margins and offshore petroleum exploration. Edited by C.J. Yorath, E.R. Parker and D.J. Glass. Canadian Society of Petroleum Geology, Memoir 4, pp. 773-790.

Dineley, D.L. and Williams, P.B.J. 1968a. Sedimentation and paleoecology of the Devonian Escuminac Formation and related strata, Escuminac Bay, Quebec. Geological Society of America, Special Paper 106, pp. 241-264.

1968b. The Devonian continental rocks of the lower Restigouche River, Quebec. Canadian Journal of Earth Science, 5, pp. 945-953.

Donohoz, H.V. and Pajari, G. 1973. The age of the Acadian deformation in Maine-New Brunswick. Maritime Sediments, 3. pp. 78-82.

DYNI, J.R. and HAwkins, J.E. 1981. Lacustrine turbidites in the Green River Formation, northwestern Color ado. Geology, 9. pp. 235-238.

Forel F.A. 1885. Les ravins sous-lacustres des fleuves glaciaires. Comptes Rendues Académie des Sciences, Paris, 101, pp. $725-728$.

1888. Le ravin sous-lacustrine du Rhône. Bulletin de Société Vaudoise des Sciences Naturelles, 23, pp. 86-107.

FÚchtBaURr, H. 1971. Cone-in-cone, a low nucleation cement in marls. In Carbonate cements. Edited by O.P. Bricker. John Hopkin's University, Studies in Geology 19, pp. 193-195.

Goldrino, R. and Lanoenstrassen, F. 1979. Open shelf and near-shore clastic facies in the Devonian. In The Devonian System. Edited by M.R. House, C.T. Srutton and M.G. Basset. Palaeontological Association, Special Paper 23, pp. 8197.

GouLD, H.R. 1951. Some quantitative aspects of Lake Mead turbidity currents. In Turbidity currents and the transportation of coarse sediment to deep water. Edited by J.L. Hough. Society of Economic Paleontologists and Mineralogists, Special Publication 2, pp. 34-52.

Greoory, M.R. 1969. Sedimentary features and penecontemporaneous slumping in the Waitemata Group. Wangaparaoa Peninsula, North Auckland, New Zealand. New Zealand Journal of Geology and Geophysics, 12, pp. 248-282.

НАвichт, J.K.A. 1979. Paleoclimate, paleomagnetism, and continental drift. American Association of Petroleum Geologists, Studies in Geology, 9, 31 p.

HAMblin, A.P. and RUST, B.R. 1989. Tectono-sedimentary analysis of alternate-polarity half-graben basin-fill successions: Late Devonian-Early Carboniferous Horton Group. Cape Breton Island, Nova Scotia. Basin Research, 2, pp. 239-255.

HeCKEL, P.H. and WITZKE, B.J. 1979. Devonian world palaeogeography determined from distribution of carbonates and related lithic palaeoclimatic indicators. In The Devonian System. Edited by M.R. House, C.T. Scrutton and M.G. Basset. Palaeontological Association, Special Paper 23, pp. 99-123.

Heroux, Y., Chagnon, A., and Bertrand, R. 1979. Compilation and correlation of the major thermal maturation indicators. American Association of Petroleum Geologists Bulletin, 63. pp. 2128-2144.

Hesse, R. and Dalton, E. 1990. Lower Devonian deep-water turbidite deposition in the Temiscouata-Fortin Groups of the 
Madawaska and Matapedia valleys, Québec and New Brunswick. In Post-Taconian evolution of the Quebec-MaineNew Brunswick Appalachians. Edited by M. Malo, D. Lavoie and D. Kirkwood. Centre Géoscientifique du Québec, pp. 1113.

1991. Diagenetic and low-grade metamorphic terrains of Gaspé-Peninsula related to geologic structure of the Taconian and Acadian orogenic belts, Quebec Appalachians. Journal of Metamorphic Geology, 9, pp. 775-790.

Hesse, R. and SA wh, H. 1982. Stop 1-2: Escuminac Formation. In Paleozoic continental margin sedimentation in the Quebec Appalachians. Edited by R. Hesse, G.V. Middleton and B.R. Rust. Excursion 7B: 11 th International Congress of Sedimentology, International Association of Sedimentologists, pp. 72-80.

Hyde, R.S., Miller, H.G., Hiscott, R.N., and Wrioht, J.A. 1988. Basin architecture and thermal maturation in the strikeslip Deer Lake Basin, Carboniferous of Newfoundland. Basin Research, 1, pp. 85-105.

KeLts, K. and Hs U, K.J. 1978. Freshwater carbonate sedimentation. In Lakes - Chemistry, geology, physics. Edited by A. Lerman. New-York, Springer Verlag, pp. 295-323.

KINDLE, E.M. 1930. Stratigraphic relations of the Upper Devonian beds and the Bonaventure Conglomerate at Escuminac Bay, Quebec. Geological Survey Canada, Summary Report 1928, Pt. C, pp. 83-89.

Kirkwood, D. and St-Julien, P. 1987. Analyse structurale de Siluro-Dévonien dans la Vallée de la Matapédia. Québec Department of Energy and Resources, MB 87-33, 17 p.

Kліонт, I. 1983. Geology of the Carboniferous Bai St. George subbasin, western New foundland. Newfoundland Department of Mines and Energy, Mineral Development Division, Memoir $1,358 \mathrm{p}$.

Lambert, A., Kelts, K., and Zimmermann, U. 1984. Trubeströme in Seen: Sauerstoffeintrag durch grundnah eingeschichtetes FluBwasser. Schweizer Zeitschrift für Hydrologie, 46, pp. 41-50.

Laurent, R. and Belanoer, J. 1984. Geochemistry of SilurianDevonian alkaline basalt suites from the Gaspe-Peninsula, Québec Appalachians. Maritime Sediments and Atlantic Geology, 20, pp. 67-78.

Link, M.H. and Osborne, R.H. 1978. Lacustrine facies in the Pliocene Ridge Basin Group: Ridge Basin, California. In Modern and ancient lake sediments. Edited by $A$. Matter and M. Tucker. International Association of Sedimentologists, Special Publication 2, pp. 169-186.

LogAn, W.E. 1846. On the geology of the Chat and Cascapedia Rivers, Gaspé, and part of Chaleur Bay. Geological Survey of Canada, Report of Progress 1844.

Marillier, F., Keen, C.E., Stockmall, G.S., Quinlan, G., Williams, H., Colman-Sadd, S.P., and O'Brien, S.J. 1989. Crustal structure and surface zonation of the Canadian Appalachians: implications of deep seismic reflection data. Canadian Journal of Earth Sciences, 26, pp. 305-321.

MIDDELBURO, J.B.M. 1990. Early diagenesis and authigenic mineral formation in anoxic sediments of Kau Bay, Indonesia. Geologica Ultraiectina 71, Mededelingen van de Faculteit Aardwetenschappen der Rijksuniversiteit te Utrecht, 177 p.

Nelson, C.H., Meyer, A.W., Thor, D., and Larsen, M. 1986. Crater Lake, Oregon: a restricted basin with base-of-slope aprons of nonchannelized turbidites. Geology, 14, pp. 238241.
ØRvio, T. 1957. Remarks on the vertebrate fauna of the Lower Upper Devonian of Escuminac Bay, P.Q., Canada, with special reference to the porolepiform Crossopterygians. Arkiv fur Zoologi, 10, pp. 367-426.

Reineck, H.-E. and WeBER, J. 1983. Trummer- und Trübeströme im eozănen See von Messel. Natur und Museum, 113, pp. 307-312.

Reinson, G.E. 1992. Transgressive barrier island and estuarine systems. In Facies models: Response to sea level change. Edited by R.G. Walker and N.P. James. Geological Association of Canada, pp. 179-194.

RUSSELL, L.S. 1939. Notes on the occurrence of fossil fishes in the Upper Devonian of Miguasha, Quebec. Contribution of the Royal Ontario Museum of Paleontology, pp. 1-10.

RUsT, B.R. 1982. Significance of alluvial sedimentation for understanding Acadian and Alleghenian orogenies in the Gaspe region. In Paleozoic continental margin sedimentation in the Quebec Appalachians. Edited by R. Hesse, G.V. Middleton and B.R. Rust. Excursion 7B: 11 th International Congress of Sedimentology, International Association of Sedimentologists, pp. 47-60.

Rust, B.R., Lawrence, D.A., and Zaitlin, B.A. 1989. The sedimentology and tectonic significance of Devonian and Carboniferous terrestrial successions in Gaspé, Quebec. Atlantic Geology, 26, pp. 1-13.

SА พн, H. 1982. Sedimentology and diagenesis for the Upper Devonian Escuminac Formation, a post-Acadian lacustrine turbidite sequence of Chaleurs Bay. Department of Geological Science, McGill University, manuscript, 174 p.

Schluger, P.R. 1973. Stratigraphy and sedimentary environments of the Devonian Perry Formation, New Brunswick, Canada, and Maine, USA. Geological Society of American Bulletin, 84, pp. 2533-2548.

Schultze, H.P. 19]2. New fossils from the Lower Upper Devonian of Miguasha. In Vertebrate paleontology of eastern Canada. Edited by R.L. Carroll, E.S. Belt, D.L. Dineley, D. Baird and D.C. McGregor. Guidebook, Excursion A-59, 24th International Geological Congress, Montreal, p. 95.

Schultze, H.P. and Arsenault, M. 1985. The panderichthid fish Elpistostege: a close relative of tetrapods? Paleontology, 28. pp. 293-309.

Schultze, H.P. and Cloutier, R. In press. Paleozoology of the Escuminac Formation: Comparison with other Frasnian faunas. In Paleontology and Geology of the Upper Devonian Escuminac Formation from Quebec, Canada. Edited by H.P. Schultze, R. Cloutier and D. Vézina. University of Kansas, Museum of Natural History, Miscellaneous Publication.

Sigoenthaler, C., Finger, W., Kelts, K., and Wano, S. 1987. Earthquake and seiche deposits in the Lake Lucerne, S witzerland. Eclogae geologicae Helvetiae, 80, pp. 241-260.

Slaughter, M. and HilL, R.J. 1991. The influence of organic matter in organogenic dolomitization. Journal of Sedimentary Petrology, 61, pp. 296-303.

Streel, M., Fairon-Dbmaret, M., and Loboziak, S. 1990. Givetian-Frasnian phytogeography of Euramerica and western Gondwana based on miospore distribution. In Palaezoic palaeogeography and biogeography. Edited by W.S. McKerrow and C.R. Scotese. Geological Society (London), Memoir 12. pp. 291-296.

StURM, M. and MATter, A. 1978. Turbidites and varves in Lake Brienz (Switzerland): Deposition of clastic detritus by density currents. In Modern and ancient lake sediments. Edited 
by A. Matter and $M$. Tucker. International Association of Sedimentologists, Special Publication 2, pp. 147-168.

Sutton, R.G., Bowen, Z.P., and McAlester, A.L. 1970. Marine shelf environments of the Upper Devonian Sonyea Group of New York. Geological Society of American Bulletin, 81, pp. 2975-2992.

Thомson, K.S. 1969. The environment and distribution of Paleozoic sarcopterygian fishes. American Journal Science, 267. pp. 457-464.

Utting, J. and Hamblin, A.P. 1991. Thermal maturity of the Lower Carboniferous Horton Group, Nova Scotia. International Journal of Coal Geology, 19, pp. 439-456.

Vézina, D. 1991. Nouvelles observations sur le facès sédimentaire de la Formation d'Escuminac (Dévonien supérieur, Frasnien), Québec, Canada. Journal Canadien de Science de la Terre, 28, pp. 225-230.

Westoll, T.S. 1979. Devonian fish biostratigraphy. In The Devonian system. Paleontology, Special Paper 23, pp. 342 353.
Williams, B.P. and Dineley, D.L. 1966. Studies of Devonian strata of Chaleur bay. Maritime Sediments, 2, pp. 7-10.

Williams, H. 1979. Appalachian orogen in Canada. Canadian Journal of Earth Sciences, 16, pp. 792-807.

Williams, H. and Hatcher, R.D., JR. 1983. Appalachian suspect terranes. In Contributions to the tectonics and geophysics of mountain chains. Edited by R.D. Hatcher, Jr., H. Williams and I. Zietz. Geological Society of America, Memoir 158, pp. 33-53.

Woodrow, D.L., Fletcher, F.W., and Ahrnsbrak, W.F. 1973. Paleogeography and paleoclimate at the deposition sites of the Devonian Catskill and Old Red facies. Geological Society of America Bulletin, 84, pp. 3051-3064.

Zaitlin, B. 1981. Sedimentology of the Pirate Cove, Fleurant and Bonaventure Formations of the western Baie des Chaleurs area, Maritime Canada; a depositional and tectonic model. Unpublished M.Sc. thesis, University of Ottawa, 164 p. 